\title{
Family Characterization of a Population of the Municipality of Puerto Colombia, Atlántico/Colombia
}

\author{
Anderson Díaz-Pérez ${ }^{1,2}$, Liliana Pérez-Lavalle ${ }^{2}$, Anabell Donado Mercado ${ }^{1}$, Gladys Gaviria García ${ }^{1,3}$, Viviana \\ Silva Torres ${ }^{1}$, Gloria Lastre Amell ${ }^{1} \&$ Aida Ferrer Parejo ${ }^{1}$ \\ ${ }^{1}$ Faculty of Health Sciences, Simón Bolívar University, Barranquilla, Colombia \\ ${ }^{2}$ Faculty de Basic and Biomedical Sciences, Simón Bolívar University, Barranquilla, Colombia \\ ${ }^{3}$ Departamento de Gestión Organizacional, Universidad de la Costa, Barranquilla, Colombia \\ Correspondence: Anderson Díaz-Pérez, Faculty of Health Sciences, Simón Bolívar University, Barranquilla, \\ Colombia. Orcid: https://orcid.org/0000-0003-2448-0953. E-mail: adiaz72@unisimonbolivar.edu.co
}

Received: September 25, 2018 Accepted: October 30, 2018 Online Published: November 9, 2018

doi:10.5539/gjhs.v10n12p70 URL: https://doi.org/10.5539/gjhs.v10n12p70

\begin{abstract}
Introduction: The family as a fundamental structure of society is exposed to different economic, social and health problems. Families in conditions of vulnerability become an element of protection but also of dominance and power; because they are born without being aware of their status or they even normalize their condition of extreme poverty, not to mention the exposure to natural hazards of their geographical area due to being in close proximity to the sea, which leads to people being grouped, creating problems of violence due to overcrowding, lack of formal employment, as well as lack of access to education or basic sanitation services. These groups are considered as social groups with limited resources.
\end{abstract}

Objective: To describe the family structure of the household head members and their main practices of managing with vulnerability states on topics as health, economic and educational in the inhabitants of the Vista Mar neighborhood in the Municipality of Puerto Colombia / Atlántico.

Methodology: Descriptive cross-sectional study with a sample of 135 inhabitants grouped into 27 families. An observation form and a survey were applied to the person of family care or economic maintenance.

Results: The level of education of the head of household has very low academic training with ages ranging from 20 to 60 years with informal occupations in $39.37 \%$.

Conclusions: The woman is responsible for the care of the members of the family and the man financially supports the home. The families are formed by adults and young people with training at the primary, secondary and technical levels.

Keywords: family, vulnerability, formal workers, public health, education

\section{Introduction}

The family as the axis and fundamental pillar of society is affected by many factors such as globalization, aging, and problems associated with health (Programas y actividades del Sistema de las Naciones Unidas por tema, s. f.). Nevertheless; several studies tend to establish the social, economic and health problems present in populations considered as vulnerable for instance is the case with the inhabitants of the Vista Mar neighborhood in the Municipality of Puerto Colombia / Atlántico, which are considered as social groups with limited resources and high relative risk of morbidity and mortality (Flaskerud \& Winslow, 1998), due to the exposure of natural risks, urban geography, accessibility, urban policy, planning or urban agglomeration and socio-economic factors (Hardy, 2017).

The family occupies an important place among the state policies since they contribute to know the dynamics of health - disease having a direct impact on population quality of life (Ortiz Gómez, Louro Bernal, Jiménez Cangas, \& Silva Ayzaguer, 1999; Pratt, 1976). It is known that the social, economic and health aspects of each family depend a lot on the conformation of their family structure and not only sociodemographic aspects (Oppenheimer, 2013; Gray, Geraghty, \& Ralph, 2016; Carreño \& Chaparro-Díaz, 2017); where the structure is defined by the interaction model (functional or dysfunctional), related to the socio-affective aspects in benefit of group progress, 
but also individually defining its economic, educational, biological, but also spiritual role as it happens in the case of who supports the family (head of family), who also has the responsibility to develop moral habits such as hygiene, so that diseases do not affect family dynamics (Parsons \& Bales, 1956; Covey, 2014; Oppenheimer, 2013).

The studies related to the problems of vulnerable families, contribute to provide information comparisons of the family structure but also of other components such as overcrowding, work activity, level of schooling, etcetera.

The analysis of the family conformation allows to make known the families weak points, and thus be able to propose and implement better ways of adopting governance of the appropriate measures from public policies (Carreño \& Chaparro-Díaz, 2017), for social construction to diminish their needs and thus contribute as stipulated by Article 16 of the Universal Declaration of Human Rights: "The family is the natural and fundamental element of society and has the right to be protected by the society and the State" but also its obligated to produce, reproduce and develop the life of each subject that is part of it.

\subsection{Objective}

Describe the family structure of heads of household and state of vulnerability in areas such as health, economic and educational dependence in the inhabitants of the Vista Mar neighborhood in the Municipality of Puerto Colombia / Atlántico, Colombia.

\section{Methods}

A descriptive cross-sectional study was conducted with a population of 135 inhabitants, which make up a universe of 27 families from the community of the Vista Mar neighborhood in the Municipality of Puerto Colombia/Atlántico.

The data was obtained through a questionnaire, open questions and an observation format developed from structural and functional variables such as: sex, school level and occupation of the responsible for the family nucleus, income per capita, overcrowding, housing conditions, family structure, among others, for a total of 15 questions validated by expert judgments. The instrument was applied to the heads of the nucleus (responsible for the family), which provided detailed information on its structure and family members. The data processing was carried out with the SPSS $21{ }^{\circledR}$ program and the $\mathrm{X}^{2}$ test was used with its respective $\mathrm{p}$-value. As the main exclusion criterion, the survey was not allowed to be answered by minors who were alone at the time of the application of the instruments.

The research was endorsed by the social extension committee of the Simon Bolívar University, which defined as the main requirement to safeguard the confidentiality of the data, whose supporting evidence was the informed consent, which also contributed to determine the degree of understanding of the participants of the study with respect to the purpose of the study as stipulated in resolution 0008430/93.

\section{Results}

A total of 27 families formed by a total of 135 persons were surveyed, to which they describe their condition of health affiliation and if they are Potential Beneficiaries of Social Programs (SISBEN), where it was determined that each family has an average of four (4) members. Two (2) children. $35 \%$ of people are between the stages of adulthood and old age according to the person responsible for responding to the instrument. (Table 1).

Table 1. Characteristics of the age persons affiliated to SISBEN

\begin{tabular}{ll}
\hline Age & $\mathrm{n}$ \\
\hline Number of participants & 135 \\
SISBEN Level & 121 \\
Age Range & $\mathrm{n}(\%)$ \\
$13-19$ & $2(1,5)$ \\
$20-26$ & $9(6,7)$ \\
$27-33$ & $16(11,9)$ \\
$34-40$ & $15(11,1)$ \\
$40-46$ & $24(17,8)$ \\
\hline
\end{tabular}




\begin{tabular}{ll}
\hline $47-53$ & $31(23)$ \\
$54-60$ & $18(13,3)$ \\
$61-66$ & $10(7,4)$ \\
$67-73$ & $5(3,7)$ \\
$74-80$ & $4(3)$ \\
$81-86$ & $1(1,07)$ \\
Total & $135(100)$
\end{tabular}

It was found that $26.54 \%$ of the people who support the household economically are women who, in addition to being housewives; they are also dedicated in $13.39 \%$ to informal work activities (Table 2).

Table 2. The sex of the person supporting the family and its relationship with the occupation, marital affiliation and the SGSS regime

\begin{tabular}{|c|c|c|c|c|c|}
\hline \multirow{2}{*}{ Occupation } & \multicolumn{2}{|l|}{ Gender } & \multirow{2}{*}{ Total n (\%) } & \multirow{2}{*}{$\mathrm{Chi}^{2}$} & \multirow{2}{*}{$p$-Value } \\
\hline & Female $\mathrm{n}(\%)$ & Male $\mathrm{n}(\%)$ & & & \\
\hline Housewife & $21(16,54)$ & $1(0,78)$ & $22(17,32)$ & \multirow{4}{*}{37,637} & \multirow{4}{*}{0,0000} \\
\hline Formal & $10(7,87)$ & $28(22,05)$ & $38(29,92)$ & & \\
\hline Informal & $17(13,39)$ & $50(39,37)$ & $67(52,76)$ & & \\
\hline Total n (\%) & $48(37,80)$ & $79(62,20)$ & $127(100)$ & & \\
\hline \multicolumn{6}{|c|}{ Head of Household with Spouse } \\
\hline Yes & $20(14,81)$ & $73(54,07)$ & $93(68,89)$ & \multirow{3}{*}{33,674} & \multirow{3}{*}{0,0000} \\
\hline No & $31(22,96)$ & $11(8,15)$ & $42(31,11)$ & & \\
\hline Total n (\%) & $51(37,78)$ & $84(62,20)$ & $135(100)$ & & \\
\hline
\end{tabular}

(\%) The percentages in relation to the row.

It is observed that $96 \%$ of the members of the family under 5 years old are in the preschool level, it is also observed that there are still adults in the primary and secondary levels. (Table 3)

Table 3. Age grouped with Level of Schooling

\begin{tabular}{|c|c|c|c|c|c|c|c|c|c|c|}
\hline & & \multicolumn{6}{|c|}{ Age (grouped) n (\%) } & \multirow{2}{*}{ Total } & \multirow{2}{*}{$\mathrm{Chi}^{2}$} & \multirow{2}{*}{$p$-Value } \\
\hline & & $<=5$ & $6-25$ & $26-45$ & $46-65$ & $66-85$ & $86+$ & & & \\
\hline \multirow{7}{*}{$\begin{array}{l}\text { Level of } \\
\text { Schooling }\end{array}$} & Illiterate & $0(0,00)$ & $0(0,00)$ & $0(0,00)$ & $8(72,7)$ & $3(27,3)$ & $0(0,00)$ & $11(100)$ & \multirow{8}{*}{454,85} & \multirow{8}{*}{0,00} \\
\hline & NRD & $12(100)$ & $0(0,00)$ & $0(0,00)$ & $0(0,00)$ & $0(0,00)$ & $0(0,00)$ & $12(100)$ & & \\
\hline & Preschool & $24(96)$ & $1(4)$ & $0(0,00)$ & $0(0,00)$ & $0(0,00)$ & $0(0,00)$ & $25(100)$ & & \\
\hline & Primary & $8(4,1)$ & $100(50,8)$ & $33(16,8)$ & $45(22,8)$ & $9(4,6)$ & $2(1)$ & $197(100)$ & & \\
\hline & High school & $2(0,9)$ & $99(43,8)$ & $71(31,4)$ & $48(21,2)$ & $6(2,7)$ & $0(0,00)$ & $226(100)$ & & \\
\hline & $\begin{array}{l}\text { Technician } \\
\text { or } \\
\text { Technologist }\end{array}$ & $0(0,00)$ & $9(31)$ & $14(48,3)$ & $5(17,2)$ & $1(3,4)$ & $0(0,00)$ & $29(100)$ & & \\
\hline & $\begin{array}{l}\text { University } \\
\text { students/ } \\
\text { Academic }\end{array}$ & $0(0,00)$ & $11(47,8)$ & $8(34,8)$ & $2(8,7)$ & $2(8,7)$ & $0(0,00)$ & $23(100)$ & & \\
\hline Total & & $46(8,8)$ & $220(42,1)$ & $126(24,1)$ & $108(20,7)$ & $21(4)$ & $2(0,4)$ & $523(100)$ & & \\
\hline
\end{tabular}

NRD: Does not report data. (\%): Within Schooling. 


\section{Discussion}

The number of members in the families of the Vista Mar community of the Municipality of Puerto Colombia was of 3.85, which coincides with that described by the National Administrative Department of Statistics in Colombia (DANE) (Microsoft Word - PerfilMunicipal.doc - 00000T7T000.PDF, s. f.), which indicates in its module of households, that the average number of people in the families of the aforementioned community is 3.8. Likewise, in the variable of the number of children by families, it was found that in the community studied, it was 1.8 , which is related to what was reported by Paz-Gómez, who refers in his study, that in Colombia, women consider having 2 children as ideal (Paz-Gómez, 2010).

It was observed that a low average of the population is affiliated with social security, which is related to the low coverage in medical care for the most vulnerable population, as mentioned by Velásquez et. al. study, which reports that $70.8 \%$ of the population affiliated to the general system of social security in health, is in the subsidized regime (Velásquez \& Gutiérrez, 2007).

Regarding the level of schooling, the highest percentage was secondary (43.2\%), and primary (37.7\%), while other study stages as the technical, preschool, and university levels presented values of $29 \% 25 \% 23 \%$ respectively, contrasting this data with García P. et al report, who identified that individuals between 2 and 4 years of age, $31 \%$ attended the preschool level, while $25 \%$ did so in a different education institution. Between the ages of 5 and $14,38 \%$ attended basic education, $31 \%$ attended preschool and only $35 \%$ attended a differential education. For the group of 15 and 20 years, $55 \%$ were still studying basic education, $11 \%$ higher education and $33 \%$ of them attended the differential education. For the population over 21 years old $50 \%$ were studying higher education, $5 \%$ in secondary education and 23\% attended the differential education (García \& Pamela San Martín, 2015).

\section{Conclusions}

When analyzing the socioeconomic conditions of the population, it was found that they do not have economic stability that contributes to the strengthening of their quality of life since the vast majority of their productivity does not exceed the minimum wage set in Colombia. To this problem is added that in a large percentage the head of household are women, who are more vulnerable to precarious working conditions, with social discrimination (gender gaps) typical of this type of population where it is evident that women have greater difficulties in finding a well-paying job.

In the present study, it was observed that the members of the family that support the home recognize the importance of the schooling of the children in their first years of life, that is to say; what is on them the duty of care of children, in addition to the cost of education at all levels since it was found that some young people were studying at a higher level.

\section{Competing Interests Statement}

The authors declare that there are no competing or potential conflicts of interest.

\section{References}

Carre-o, S. P., \& Chaparro-Díaz, L. (2017). Groups of Family Caregivers in Colombia: Profile, Caregiving Ability and Overburdening. Pensamiento Psicológico, 15(1), 87-101.

Covey, S. R. (2014). The 7 habits of highly effective families. St. Martin's Press. Retrieved from https://books.google.es/books?hl=es\&lr=\&id=OmrfAwAAQBAJ\&oi=fnd\&pg=PP1\&dq=The+family+struct ure+defines + how + the + family+interacts, + but + also+the+effective+functioning\&ots $=$ KO5il Ta3MO\&sig $=1 \mathrm{~W}$ YSq6JQqXMX_R4jRjH01AmyefM

Flaskerud, J. H., \& Winslow, B. J. (1998). Conceptualizing vulnerable populations health-related research. Nursing research, 47(2), 69-78. https://doi.org/10.1097/00006199-199803000-00005

García, D., \& Pamela San Martín, P. (2015). Caracterización sociodemográfica y clínica de la población atendida en el Instituto Teletón de Santiago. Revista chilena de pediatría, 86(3), 161-167. https://doi.org/10.1016/j.rchipe.2015.06.002

Gray, J., Geraghty, R., \& Ralph, D. (2016). Family rhythms: The changing textures of family life in Ireland. Oxford University Press. Retrieved from https://books.google.es/books?hl=es\&lr=\&id=eofJDgAAQBAJ\&oi=fnd\&pg=PP1\&dq=The+social,+econo mic + and + health + aspects + of + each + family + depend + very + much + on + the + conformation + of + the + family + stru cture + and + not + only+on+socio+demographic + aspects\&ots=cztvQACmNd\&sig=gn5wmXRFwYEBo0_DO2M00TXHA0 
Hardy, S. (2017). Atlas de la vulnérabilité de l'agglomération de La Paz. IRD Éditions.

Oppenheimer, V. K. (2013). Work and the family: A study in social demography. Elsevier. Retrieved from https://books.google.es/books?hl=es\&lr=\&id=riOLBQAAQBAJ\&oi=fnd\&pg=PP1\&dq=The+social,+econo mic + and + health + aspects + of + each + family + depend + very + much + on + the + conformation + of + the + family + stru cture + and + not + only + on + socio+demographic + aspects\&ots=M5rsqhVGAy\&sig=ZJ4mIAn_VYdrcI9lmV53 MbTPr7U

Ortiz Gómez, M. T., Louro Bernal, I., Jiménez Cangas, L., \& Silva Ayzaguer, L. C. (1999). La salud familiar: caracterización en un área de salud. Revista Cubana de Medicina General Integral, 15, 303-309.

Parsons, T., \& Bales, R. F. (1956). Family socialization and interaction process (Vol. 7). Psychology Press. Retrieved from https://books.google.es/books?hl=es\&lr=\&id=uh0VXFUutmAC\&oi=fnd\&pg=PA3\&dq=The+family+struct ure+defines + how + the + family + interacts, + but + also + the+effective + functioning\&ots $=$ sAZ0cIn $8 \mathrm{fw} \&$ sig $=\mathrm{yM} 6$ lyBjTcEQC1i7EriH8amimn0o

Paz-Gómez, L. (2010). Tama-o de familia deseado. Un análisis sobre los ideales de fecundidad en Colombia y México. Papeles de población, 16(65), 105-130.

Pratt, L. V. (1976). Family structure and effective health behavior: The energized family. Houghton Mifflin Harcourt (HMH).

Programas y actividades del Sistema de las Naciones Unidas por tema. (s. f.). Recuperado 27 de junio de 2017, a partir de http://www.un.org/es/globalissues/family/

Velásquez, C. I. V., \& Gutiérrez, V. F. F. V. (2007). Caracterización del riesgo familiar total en las familias con adultos mayores funcionales, sector de Patio Bonito, Bogotá, 20051. Avances en Enfermería, 25(2), 10-21.

\section{Copyrights}

Copyright for this article is retained by the author(s), with first publication rights granted to the journal.

This is an open-access article distributed under the terms and conditions of the Creative Commons Attribution license (http://creativecommons.org/licenses/by/4.0/). 